Article

\title{
Illegal Waste Dumping under a Municipal Solid Waste Charging Scheme: Application of the Neutralization Theory
}

\author{
Amanda M. Y. Chu
}

check for

updates

Citation: Chu, A.M.Y. Illegal Waste Dumping under a Municipal Solid Waste Charging Scheme: Application of the Neutralization Theory. Sustainability 2021, 13, 9279. https:// doi.org/10.3390/su13169279

Academic Editor: Munjed A. Maraqa

Received: 29 June 2021

Accepted: 6 August 2021

Published: 18 August 2021

Publisher's Note: MDPI stays neutral with regard to jurisdictional claims in published maps and institutional affiliations.

Copyright: (C) 2021 by the author. Licensee MDPI, Basel, Switzerland. This article is an open access article distributed under the terms and conditions of the Creative Commons Attribution (CC BY) license (https:// creativecommons.org/licenses/by/ $4.0 /)$.
Department of Social Sciences, The Education University of Hong Kong, Hong Kong, China; amandachu@eduhk.hk

\begin{abstract}
Illegal waste dumping has become a threat to human health and the global environment. In Hong Kong, the government has proposed a quantity-based municipal solid waste charging scheme to reduce waste. However, individuals may still dispose of waste improperly, even if such a scheme has been implemented. In this study, the neutralization theory was adopted and an online survey with 273 respondents was conducted to examine the reasons for improper dumping intentions. A principal component analysis identified two types of neutralization: intrinsic neutralization (including denial of responsibility, denial of injury, and defense of necessity) and extrinsic neutralization (including condemnation of the condemners and appeal to higher loyalties). A regression analysis showed that intrinsic neutralization and gender were significant factors for illegal waste dumping intentions when attitude toward illegal waste dumping was controlled.
\end{abstract}

Keywords: environmental sustainability; illegal waste disposal; neutralization techniques; public health; waste management

\section{Introduction}

Illegal waste dumping has become a threat to human health and the global environment [1]. Hong Kong has a high population density, and the waste generated from its human activities is massive. The Hong Kong Environmental Protection Department [2] reported that the amount of daily waste received at landfills in 2019 was 15,637 tons, of which 11,057 tons $(70.7 \%)$ were municipal solid waste. In response to the major source of the waste, the Hong Kong government proposed a quantity-based municipal solid waste (MSW) charging scheme, which is awaiting passage by the Hong Kong Legislative Council. Although that new policy is the first of its kind in Hong Kong, our neighbors have had successful experiences. The amounts of domestic waste in Taipei City and Seoul have declined significantly since the implementation of their MSW charging schemes. Between 1999 and 2009, the generation of domestic waste in Taipei City decreased from $1.10 \mathrm{~kg}$ per person per day to $0.88 \mathrm{~kg}$, and between 1994 and 2011 in Seoul, domestic waste disposal garbage declined from $1.3 \mathrm{~kg}$ per household per day to $0.95 \mathrm{~kg} /$ day [3]. These positive examples imply that an MSW charging scheme, which increases the economic cost to citizens for generating waste, could be an effective program for handling Hong Kong's waste problem.

However, research has revealed that a charging scheme can lead to increases in illegal waste dumping [4]. In Japan, the amount of illegal dumping rose after the implementation of a set of legal restrictions on domestic waste [5]. In other words, individuals may still dispose of waste improperly, even though they understand that it is harmful to the environment and that an MSW charging scheme has been implemented. To sustain a successful waste management program, we have to examine such a phenomenon. The aim of this study was to investigate the discrepancy between people's attitude toward illegal waste dumping and their intention toward illegal waste dumping. The neutralization theory [6] was adopted in the investigation. 


\subsection{Neutralization Theory}

The neutralization theory was developed in 1957 by criminologists Gresham Sykes and David Matza in a study on juvenile delinquency [6], in which the authors observed that delinquents justified their deviant behavior as being acceptable in order to protect themselves from self-blame and the blame of others and to preserve their self-image. Sykes and Matza [6] referred to the techniques that the juveniles used as neutralization techniques and identified them as denial of responsibility, denial of injury, denial of the victim, condemning the condemners, and appeal to higher loyalties. Denial of responsibility is the application of the argument that an individual is not responsible for a behavior because it is beyond his/her control and is caused by something or someone outside of the individual. Denial of injury involves justifying one's negative behavior by saying that little or no harm was caused by the behavior. With denial of the victim, an individual argues that no victim exists, or alternatively that the victim deserves it. Condemning the condemners is a way to shift the focus to the person who disapproves of one's violation or to the rule that restricts one's behavior. In an appeal to higher loyalties, an individual seeks to justify his/her behavior as resulting from a greater good and a higher-order value.

In addition to those original five neutralization techniques, in a study on criminal offence committed by juveniles and youngsters, Minor [7] identified two additional techniques: defense of necessity and metaphor of the ledger. Defense of necessity is the argument that the behavior is necessary and cannot be avoided, whereas the metaphor of the ledger is the argument that sufficient previous good acts and a surplus of good will can compensate for one's bad action [8].

Application of the neutralization theory is not limited to juvenile crime. It also applies to deviant behaviors that bring negative effects or disobedience in response to restrictions from the authorities. Researchers have used the neutralization theory to investigate deviant behavior regarding information security [9-11]. Brunner [12] applied the neutralization theory to explain why consumers are irresolute about buying more fair-trade products, and Siponen and Vance [13] adopted the theory to investigate how employees rationalize their violations of security policy. In $[12,13]$, the researchers did not use the "denial of victim" technique since it was difficult to identify the victims within the scope of their studies.

\subsection{Neutralization Theory and Illegal Waste Dumping}

Illegal waste dumping is considered to be a socially undesirable behavior since it contributes pollution to the environment. Nonetheless, people may utilize neutralization techniques to rationalize such negative behavior. As is the case with people performing other types of socially undesirable behaviors (e.g., deviant behaviors regarding information security), individuals may use neutralization techniques to assuage their feelings of guilt or shame about dumping waste illegally and thus to rationalize to themselves their violation of an MSW charging scheme. McGovern [14] interviewed 27 senior-age women (with a mean age over 72) in America to obtain their viewpoints on the cost for rubbish disposal and found that they cut their household costs by 'sharing' rubbish collection costs with neighbors. Unfortunately, this behavior is a crime. In the study, McGovern analyzed the interviewees' comments intuitively for terminology reflecting the original five techniques of neutralization. This qualitative research provided us some insights to explore illegal waste dumping using the neutralization theory. To empirically investigate individuals ${ }^{\prime}$ intention to dump waste illegally, a causal model was developed and five neutralization techniques were examined in this study: (1) denial of responsibility; (2) denial of injury; (3) defense of necessity; (4) condemnation of the condemners; and (5) appeal to higher loyalties. A summary of these five neutralization techniques with application to illegal waste dumping is shown in Table 1. 
Table 1. A summary of five neutralization techniques with application to illegal waste dumping.

\begin{tabular}{ccc}
\hline Neutralization Technique & Description & Example of Argument \\
\hline Denial of responsibility & $\begin{array}{c}\text { Individuals pretending to lack an understanding } \\
\text { of the regulations against illegal waste dumping }\end{array}$ & $\begin{array}{c}\text { It is OK to dump waste at an unauthorized } \\
\text { area if you don't understand the law. }\end{array}$ \\
\hline Denial of injury & Acknowledge no harm that such dumping causes & $\begin{array}{c}\text { It is OK to dump waste at an unauthorized } \\
\text { area if no damage is done to others. }\end{array}$ \\
\hline $\begin{array}{c}\text { Defense of necessity } \\
\text { The belief that one lacks alternatives to illegal } \\
\text { due to the lack of financial resources or the time to } \\
\text { handle the necessary work. }\end{array}$ & $\begin{array}{c}\text { It is alright to dump waste at an unauthorized } \\
\text { area under circumstances in which it seems } \\
\text { that you have little other choice. }\end{array}$ \\
\hline $\begin{array}{c}\text { Condemnation of the } \\
\text { condemners }\end{array}$ & $\begin{array}{c}\text { Justifying illegally dumping waste by blaming the } \\
\text { charging scheme as being unfair/unjust. }\end{array}$ & $\begin{array}{c}\text { It is not as wrong to break the law of illegal } \\
\text { waste dumping if the law seems too restrictive }\end{array}$ \\
\hline Appeal to higher loyalties & $\begin{array}{c}\text { Individuals sacrifice the benefits to society that } \\
\text { compliance with the restrictions brings because of } \\
\text { their own sense of having a personal higher-order } \\
\text { value (e.g., household to which one belongs). }\end{array}$ & $\begin{array}{c}\text { It is alright to dispose of waste at an } \\
\text { unauthorized area if it is beneficial to my } \\
\text { household. }\end{array}$ \\
\hline
\end{tabular}

In this study, two neutralization techniques were excluded, including denial of the victim and the metaphor of the ledge. With the denial of the victim technique, it is difficult to identify the victim of the negative behavior under the scenario of illegal waste disposal in Hong Kong [12,13]. In addition, Eliason and Dodder [15] pointed out that the explanatory power of denial of the victim is weaker than the original five techniques proposed by Sykes and Matza [6]. The metaphor of the ledger technique was excluded since there are no reasonable, good acts to compensate for the harm done in the context of illegal waste dumping [16].

Gender, age, and educational level were included to test whether those demographics affected individuals' intention to dump waste illegally. A previous study suggested that females are more likely to engage in environmentally protective behavior [17]. In addition, the age effect may exist in the illegal waste dumping issue since the habit of receiving information can vary significantly in different age groups and thus can affect individuals' perception of illegal waste differentially. Furthermore, Sotamenou, De Jaeger, and Rousseau [18] suggested that improved education could help in reducing illegal waste disposal.

This study investigated the predictive power that the five selected neutralization techniques exerted on illegal waste dumping, and included the three demographic factors and the attitude toward illegal waste dumping. The MSW charging scheme could be an effective measure for managing waste problems and reducing pollution, but violating that scheme will have a strong negative impact on the scheme's effectiveness and will create extra administrative costs if people dump their waste in secret places, which then require more manpower to track and notice. Therefore, it is important to understand the factors that are useful in encouraging people to follow the MSW charging scheme.

The rest of the paper is organized as follows. Section two describes how the data were collected and analyzed. Sections three and four presents and discusses the research findings, respectively. Section five summarizes the conclusions that can be drawn from the research findings.

\section{Methodology}

\subsection{Participants}

The target respondents were adults in Hong Kong who were 18 years of age or older. Data was collected through an online survey. An email invitation, an information sheet, and a hyperlink to the survey was sent to 1,000 target respondents who were identified through the database of a market research company. Ultimately, 273 valid responses were obtained. The demographic characteristics of the sample are shown in Table 2. The sample was diverse, with $47.6 \%$ of the respondents being female and $49.5 \%$ of the respondents 
being 39 years old or younger. Some $40.7 \%$ of the respondents held a bachelor's degree or above. Approximately three-quarters (75.1\%) of the respondents were employed, and the remaining one-quarter $(24.9 \%)$ of the respondents were homemakers, retired, or others.

Table 2. Demographic characteristics of the sample.

\begin{tabular}{lcc}
\hline & Frequency & Percentage (\%) \\
\hline Gender & & \\
$\quad$ Female & 130 & 47.6 \\
Male & 143 & 52.4 \\
Age & & \\
$\quad 39$ years old or below & 135 & 49.5 \\
$\quad$ 40 years old or above & 138 & 50.5 \\
Educational level & & \\
$\quad$ Non-degree holder or below & 162 & 59.3 \\
Bachelor's degree or above & 111 & 40.7 \\
Employment status & & 75.1 \\
$\quad$ Employed & 205 & 12.4 \\
Homemaker & 34 & 6.6 \\
$\quad$ Retired & 18 & 5.9 \\
$\quad$ Others & 16 & \\
\hline
\end{tabular}

\subsection{Measures}

The items for the five neutralization techniques were developed with reference to [13]. The items were measured on a seven-point Likert scale ( $1=$ strongly disagree; 7 = strongly agree), with higher scores showing higher levels of agreement on a neutralization item. All items for the five neutralization techniques can be found in the first column of Table 3 . The items to assess attitude and intention toward illegal waste dumping were based on the work of Chu, Chau, and So [19], which can be found in the first column of Table 4. Three items were used to measures the participants' attitude toward dumping waste illegally, and if they held a more positive attitude toward dumping waste illegally, their scores were higher (e.g., 1 = illegal dumping is very unpleasant; 7 = illegal dumping is very pleasant). For the intention to dump waste illegally under a waste charging scheme, a seven-point Likert scale ( 1 = strongly disagree; 7 = strongly agree) were used and three items to measure it. The intention to dump waste illegally was assessed using a scenario method, which is a common means of assessing antisocial and unethical behavior [20]. Respondents indicated their intention to dump waste illegally based on the following scenario, with reference to the Hong Kong government's proposal of the MSW charging scheme:

Taylor resides in a building with the quantity-based waste charging scheme implemented. He needs to buy specified garbage bags from the property management for waste dumping, and return the bags to a designated collection point. The money spent on buying the garbage bags is regarded as the waste charge. The property management would strictly follow the scheme practice. On average, Taylor needs to spend waste charge of HKD $\$ 44$ ( USS5.5) per month for his family with three members.

\subsection{Statistical Analyses}

An exploratory factor analysis with a principal component analysis was first conducted to identify the components of the neutralization techniques. After that, a composite score for each component was calculated, generating the composite score by averaging the scores of all items involved in a component. The composite scores for attitude and for intention were also calculated by taking the average of the items involved in the attitude construct and in the intention construct, respectively. Then, an ordinary least squares (OLS) regression was used to test which factors were significant predictors of the intentional behavior to dump waste illegally. The independent variables were gender, age, educational level, the components of the neutralization techniques, and attitude toward dumping waste illegally, and the dependent variable was the intention to dump waste illegally. 
Table 3. Neutralization items, with means, standard deviations, and factor loadings.

\begin{tabular}{|c|c|c|c|c|}
\hline \multirow{2}{*}{ Item } & \multirow{2}{*}{ Mean } & \multirow{2}{*}{ SD } & \multicolumn{2}{|c|}{ Factor Loading } \\
\hline & & & Intrinsic & Extrinsic \\
\hline \multicolumn{5}{|l|}{ Denial of responsibility } \\
\hline It is OK to dump waste at an unauthorized area if you are not sure what the law is. & 2.96 & 1.43 & 0.765 & 0.257 \\
\hline It is OK to dump waste at an unauthorized area if the law is not advertised. & 3.04 & 1.54 & 0.801 & 0.209 \\
\hline It is OK to dump waste at an unauthorized area if you don't understand the law. & 2.95 & 1.51 & 0.822 & 0.255 \\
\hline \multicolumn{5}{|l|}{ Denial of injury } \\
\hline It is OK to dump waste at an unauthorized area if no harm is done. & 2.71 & 1.40 & 0.783 & 0.340 \\
\hline It is OK to dump waste at an unauthorized area if no damage is done to others. & 2.62 & 1.37 & 0.806 & 0.325 \\
\hline It is OK to dump waste at an unauthorized area if no one gets hurt. & 2.51 & 1.34 & 0.781 & 0.302 \\
\hline \multicolumn{5}{|l|}{ Defense of necessity } \\
\hline $\begin{array}{l}\text { It is alright to dump waste at an unauthorized area under circumstances in which it seems } \\
\text { that you have little other choice. }\end{array}$ & 3.03 & 1.49 & 0.762 & 0.337 \\
\hline $\begin{array}{l}\text { It is acceptable to dump waste at an unauthorized area under circumstances in which it } \\
\text { seems that there is no other option. }\end{array}$ & 3.33 & 1.57 & 0.746 & 0.325 \\
\hline It is alright to dump waste at an unauthorized area if the situation requires you to do so. & 2.94 & 1.41 & 0.673 & 0.479 \\
\hline \multicolumn{5}{|l|}{ Condemnation of the condemners } \\
\hline It is not as wrong to break the law of illegal waste dumping if the law seems unjustified. & 2.70 & 1.40 & 0.262 & 0.812 \\
\hline It is not as wrong to break the law of illegal waste dumping if the law seems too restrictive. & 2.68 & 1.33 & 0.288 & 0.845 \\
\hline It is not as wrong to break the law of illegal waste dumping if the law seems unfair to you. & 2.62 & 1.29 & 0.248 & 0.859 \\
\hline \multicolumn{5}{|l|}{ Appeal to higher loyalties } \\
\hline It is alright to dispose of waste at an unauthorized area if it is beneficial to my household. & 2.25 & 1.14 & 0.347 & 0.766 \\
\hline $\begin{array}{l}\text { It is alright to dispose of waste at an unauthorized area for the purpose of relieving my } \\
\text { household's financial difficulty. }\end{array}$ & 2.44 & 1.24 & 0.338 & 0.781 \\
\hline $\begin{array}{l}\text { It is alright to dispose of waste at an unauthorized area if a household member or a } \\
\text { significant other needs me to do so. }\end{array}$ & 2.30 & 1.17 & 0.326 & 0.683 \\
\hline
\end{tabular}

Table 4. Cronbach's $\alpha$ values for the attitude and intention constructs and the means and standard deviations of their items.

\begin{tabular}{|c|c|c|c|}
\hline Item & Mean & SD & Cronbach's $\alpha$ \\
\hline Attitude & & & 0.969 \\
\hline Dumping waste illegally is a $(1=$ very bad $-7=$ very good $)$ idea. & 2.25 & 1.37 & \\
\hline Dumping waste illegally is a $(1=$ very foolish $-7=$ very wise $)$ idea. & 2.27 & 1.37 & \\
\hline Dumping waste illegally is ( $1=$ very unpleasant $-7=$ very pleasant $)$. & 2.29 & 1.39 & \\
\hline Mean composite score for attitude & 2.27 & 1.34 & \\
\hline Intention & & & 0.859 \\
\hline I would intend to dump waste illegally ( $1=$ strongly disagree- $7=$ strongly agree $)$. & 2.10 & 1.23 & \\
\hline I would try to dump waste illegally ( $1=$ strongly disagree $-7=$ strongly agree). & 2.09 & 1.19 & \\
\hline I would plan to dump waste illegally ( $1=$ strongly disagree $-7=$ strongly agree $)$. & 2.12 & 1.34 & \\
\hline Mean composite score for intention & 2.10 & 1.11 & \\
\hline
\end{tabular}

\section{Results}

\subsection{Descriptive Statistics}

The second and third columns of Table 3 display the means and standard deviations for the neutralization items $(1=$ strongly disagree; $7=$ strongly agree $)$. It is found that the mean range was from $2.25(\mathrm{SD}=1.14)$ on the item "It is alright to dispose of waste at an unauthorized area if it is beneficial to my household." to $3.33(\mathrm{SD}=1.57)$ on the item "It is acceptable to dump waste at an unauthorized area under circumstances in which it seems that there is no other option.", representing that while respondents have some differentiation on the agreement to the items they tended to disagree than to agree with the items as a whole. In the second and third columns of Table 4, we can find that the mean and SD values of the items for attitude toward illegal waste dumping and behavioral intention. The mean composite score for attitude was $2.27(\mathrm{SD}=1.34)$ while that for intention was 2.10 
$(\mathrm{SD}=1.11)$. It seems that respondents, in general, had a negative attitude toward illegal waste dumping and low intention on the dumping.

\subsection{Principal Component Analysis}

Prior to the principal component analysis, I assessed the psychometric adequacy of the data collected. The Kaiser-Meyer-Olkin's measure of sampling adequacy was 0.909, which is above the minimum criterion of 0.5 , thus indicating that the sample size was adequate for factor analysis [21]. The Bartlett's Test of Sphericity was statistically significant $(\mathrm{x} 2=4359.865 ; \mathrm{df}=105 ; p<0.001)$, indicating that the neutralization items were adequately correlated for a factor analysis to be performed [22]. A principal component analysis was conducted for the 15 neutralization items to analyze the interrelationships of the items. Two widely used criteria were adopted, including Kaiser's eigenvalue rule [23] and Cattell's scree test [24], to determine the number of factors that should be extract. Kaiser's eigenvalue rule suggests the eigenvalues of the factors extracted should be greater than 1 . Based on the Eigenvalue criterion, two factors were identified because only the first two eigenvalues were larger than 1 (first: 8.943; second: 1.683) and explained a total variance of $71 \%$ with the Cronbach's $\alpha$ values for the two factors were 0.944 and 0.922 . The scree-plot also suggested a two-factor model as there is a distinct elbow in the scree plot at the point labeled " 3 ". The items and their factor loadings are presented in Table 3. It is found that all items in the same factor have factor weight over 0.6 . In addition, each item is clearly defined by only one factor and a difference between weights for any given item is more than 0.1 across factors [25]. The first factor included all items for the denial of responsibility, denial of injury, and defense of necessity which concern individuals, and thus it was labeled as intrinsic neutralization. For the second factor, which included all items for the condemnation of the condemners and the appeal to higher loyalties that concern external factors (law and household), the component was labeled as extrinsic neutralization.

\subsection{Attitude and Intention to Dump Waste Illegally}

Three items each were used to measure the respondents' attitude toward illegal waste dumping and their intention to dump waste illegally. The Cronbach's $\alpha$ of these two constructs and the means and standard deviations of the items involved are presented in Table 4 . Both the attitude and intention constructs showed a high internal reliability, with Cronbach's $\alpha$ values of 0.969 and 0.859 , respectively.

\subsection{Regression Analysis}

The OLS regression analysis used the intention to dump waste illegally as the dependent variable, which was represented by the calculated composite score for intention. The independent variables with their coefficients are listed in Table 5. Since those variables were measured under various scales, the standardized regression coefficients are also presented. Among the three demographic factors, only gender was a significant predictor of the individuals' illegal dumping intention, and females had a stronger tendency not to dump waste illegally than males did. Of the two types of neutralization, intrinsic neutralization significantly predicted the respondents' intention, whereas extrinsic neutralization was not a significant predictor. The respondents' attitude was also a significant factor for their intention. Referring to the standardized regression coefficients, attitude had the highest predictive power, followed by gender, and then by intrinsic neutralization. 
Table 5. OLS regression analysis results.

\begin{tabular}{lccc}
\hline \multicolumn{1}{c}{ Variable } & $\boldsymbol{\beta}$ & SE & Standardized $\boldsymbol{\beta}$ \\
\hline Constant & -0.240 & 0.380 & \\
Educational level & 0.160 & 0.115 & 0.071 \\
Gender & $0.653^{*}$ & 0.335 & 0.295 \\
Age & 0.506 & 0.334 & 0.229 \\
Intrinsic neutralization & $0.220^{* *}$ & 0.062 & 0.240 \\
Extrinsic neutralization & 0.107 & 0.072 & 0.103 \\
Attitude toward illegal waste dumping & $0.342^{* * *}$ & 0.042 & 0.412 \\
\hline
\end{tabular}

$\mathrm{R}^{2}=0.33 .{ }^{*} p<0.1 ;{ }^{* *} p<0.01 ; * * * p<0.001$. Coding for Educational level: Non-degree or below $=0$; Bachelor's degree or above $=1$. Coding for Gender: Female $=0 ;$ Male $=1$. Coding for Age: 39 years old or below $=0 ; 40$ years old or above $=1 . \beta$, regression coefficient; SE, standard error; Standardized $\beta$, standardized regression coefficient.

\section{Discussion}

\subsection{Application of the Neutralization Theory}

In the present study, it was found that the intrinsic neutralization (i.e., (1) denial of responsibility, (2) denial of injury, and (3) defense of necessity) was significant predictor of the intention to dump waste illegally under the MSW charging scheme. Interestingly, such an association was not found in the extrinsic neutralization, which included (1) condemnation of the condemners and (2) appeal to higher loyalties. Those results may be due to the nature of the behavior. Some extant studies have provided evidence that the correlation between a particular type of behavior and a particular technique of neutralization may be a viable distinction due to the different natures of the behavior [14,15]. In the present situation in Hong Kong, waste dumping is a highly personal behavior. Individuals in households pack up and dispose of their household waste at a collection point, which is most often an open area or a shared area, anytime. Then, the government collect the waste from the collection points regularly for the transfer of waste to the strategic landfills. In other words, the source of the waste cannot be easily traced and identified and no human-human interaction is needed in the waste disposal process. In the current study, intrinsic neutralization was the neutralization strategy that reflected the individual's personality and related to the individual's personal evaluation of the behavior.

However, extrinsic neutralization was the neutralization strategy that related to blaming on others or dealing with other people. From the research findings that intrinsic neutralization is a significant factor but extrinsic neutralization is not for the intention to dump waste illegally, it seems that respondents found excuses to neutralize the guilt of illegal waste dumping from an individual perspective rather than an external perspective. Offenders might use different neutralization techniques in illegal waste dumping, even if the situation is slightly different. McGovern [14] interviewed 27 senior-age women in America and found that they disposed of their waste in the dumpsters of their neighbors in order to cut their own rubbish collection costs. Denial of the victim, denial of responsibility, and appeal to higher loyalties were used to explain such behavior. Interestingly, those associated neutralization techniques were dissimilar to those in the current study, with the major difference perhaps being the identification of the victim. In McGovern's findings [14], the women understood who paid the charges for them, which could fit the characteristics of the denial of the victim technique. In addition, those respondents did not feel that their behavior was unlawful, but instead that it was a case of their neighbors who paid "just helping out a neighbor".

Our research findings extend the application of the neutralization theory to human behavior regarding environmental sustainability issues since, to the best of our understanding, the theory had not been empirically applied in such issues. Vlek and Steg [26] pointed out that changes in the global environment are driven by the evolution of human society. In other words, environmental sustainability depends on human activities, including our daily decisions about many environmental protection issues such as product consumption and waste dumping. However, our unsustainable behaviors are part of a vicious cycle. 
The traditional market and the state institutions are disincentives of sustainable behaviors, and there is lack of momentum for change, which then creates more unsustainable behaviors [27]. From our research findings in this current study, the neutralization theory may provide a direction for understand the psychological activities of people performing unsustainable behaviors [12].

\subsection{Other Factors Affecting Intention to Dump Waste Illegally}

In addition to the effect of intrinsic neutralization, the respondents' attitude toward illegal waste dumping and their gender were significant factors affecting their intention to dump waste illegally. In accord with our expectations and with previous research findings, attitude is an important factor in predicting one's intention to perform a behavior, including unethical and socially undesirable behaviors [28-31]. Regarding the effect of the gender difference on illegal waste dumping, our survey results support previous research findings that revealed that women display higher levels of environmental concern than men do [17]. The difference between males and females in terms of environmental behaviors was also noticed in a piece of research on Hong Kong secondary school students [32]. Age and educational level were not influential factors affecting the respondents' intention to dump waste illegally. That somewhat surprising finding may be due to the fact that there is, in general, a growing concern about environmental protections, and we now have many opportunities to spread knowledge about environmental sustainability, for all ages and all levels of education. For example, many environmentally related activities are organized for students and the general public, and are funded and supported by governmental entities [2,33]. The research findings may provide some insights for the policymakers to formulate a better strategy to effectively implement the quantity-based MSW charging scheme in Hong Kong.

\subsection{Limitations of the Study and Future Research}

Since the Hong Kong MSW charging scheme has not yet been put into practice, the locations in which people may dump their waste illegally are unknown. The situations may in fact be varied because of different types of households and living surroundings. It would be an interesting research direction to investigate individuals' habits toward dumping waste illegally after the MSW charging scheme has been implemented. In addition, researchers may wish to extend the research model to include specific characteristics of a situation and its criminal opportunities [34-36]. Another important research direction would be to study the change in individuals' waste generation and dumping behaviors, evaluating the effectiveness of the MSW charging scheme. Rather than just monitoring the amount of waste involved, we should also trace specific groups of people to understand their changes under the scheme, no matter whether those changes are positive or negative.

In this study, the intention to dump waste illegally was measured, rather than the actual behavior, since Hong Kong's MSW charging scheme had not yet been implemented. However, numerous studies have suggested that there is a high correlation between intention and actual behavior [37,38]. In addition, self-reporting may bring concerns about the validity of our data, since some respondents may have hidden their true thoughts. To encourage honest responses, the participants was recruited through a market research company that had already built a trusting relationship with the target respondents and used an anonymous survey to protect data privacy [19].

\section{Conclusions}

Waste from human activities is becoming a growing threat to the environmental sustainability of the earth. In addition, our waste leads to negative impacts on human health [39]. Therefore, effective waste management policies and positive household waste behaviors are needed to control the amount of waste we produce [40]. However, many individuals may attempt to escape paying disposal charges and instead may choose to dump their waste illegally, which produces unexpected pollution of the environment. In 
this study, I attempted to investigate such a phenomenon by using the neutralization theory. It was found that in addition to peoples' attitude toward illegal waste dumping, intrinsic neutralization and gender were both significant factors that helped predict individuals ${ }^{\prime}$ intentions to dump waste illegally. Neutralization theory remains an underdeveloped theory although it has been a popular framework for understanding deviant behavior [16]. Few empirical research has been done to connect it to human behavior regarding environmental sustainability issues. In terms of theoretical contributions, we demonstrate how the neutralization theory can be used to study illegal waste dumping which forms a basis for further research work. Regarding practical significance, the research findings may provide some insights for policymakers to develop an appropriate promotional strategy and design a charging scheme that enhances its effectiveness.

Funding: This research received no external funding.

Conflicts of Interest: The author declares no conflict of interest.

\section{References}

1. Triassi, M.; Alfano, R.; Illario, M.; Nardone, A.; Caporale, O.; Montuori, P. Environmental pollution from illegal waste disposal and health effects: A review on the "triangle of death". Int. J. Environ. Res. Public Health 2015, 12, 1216-1236. [CrossRef]

2. Hong Kong Environmental Protection Department. Monitoring of Solid Waste in Hong Kong-Waste Statistics for 2019. Available online: https: / / www.wastereduction.gov.hk/sites/default/files/msw2019tc.pdf (accessed on 1 June 2021).

3. United Nations. Sustainable Development Goals Policy Brief Series No. 3, United Nations. Available online: https://www.undp. org/content/dam/uspc/docs/USPC\%20Policy\%20Brief\%203.pdf (accessed on 2 June 2021).

4. Yang, H.L.; Innes, R. Economic incentives and residential waste management in Taiwan: An empirical investigation. Environ. Resour. Econ. 2007, 37, 489-519. [CrossRef]

5. Lee, S.C.; Na, S.I. E-waste recycling systems and sound circulative economies in East Asia: A comparative analysis of systems in Japan, South Korea, China and Taiwan. Sustainability 2010, 2, 1632-1644. [CrossRef]

6. Sykes, G.; Matza, D. Techniques of neutralization: A theory of delinquency. Am. Sociol. Rev. 1957, 22, 664-670. [CrossRef]

7. Minor, W.W. Techniques of neutralization: A reconceptualization and empirical examination. J. Res. Crime Delinq. 1981, 18, 103-120. [CrossRef]

8. Li, J.C.M. Neutralization techniques, crime decision-making and juvenile thieves. Int. J. Adolesc. Youth 2008, 14, $251-265$.

9. Hinduja, S. Neutralization theory and online software piracy: An empirical analysis. Ethics Inf. Technol. 2007, 9, 187-204. [CrossRef]

10. Cheng, L.; Li, W.; Zhai, Q.; Smyth, R. Understanding personal use of the Internet at work: An integrated model of neutralization techniques and general deterrence theory. Comput. Hum. Behav. 2014, 38, 220-228. [CrossRef]

11. Chu, A.M.Y.; Chau, P.Y.K.; So, M.K.P. Developing a typological theory using a quantitative approach: A case of information security deviant behavior. Commun. Assoc. Inf. Syst. 2015, 37, 510-535. [CrossRef]

12. Brunner, T.A. Applying neutralization theory to fair trade buying behaviour. Int. J. Consum. Stud. 2014, 38, 200-206. [CrossRef]

13. Siponen, M.; Vance, A. Neutralization: New insights into the problem of employee information systems security policy violations. MIS Q. 2010, 34, 487-502. [CrossRef]

14. McGovern, V. Trash Talk: FEE EVASION and Techniques of Neutralization by Older Women in Response to Rising Garbage Collection Fees. 2010. Available online: http:/ / citeseerx.ist.psu.edu/viewdoc/download?doi=10.1.1.466.9724\&rep=rep1\&type= pdf (accessed on 1 June 2021).

15. Eliason, S.L.; Dodder, R.A. Techniques of neutralization used by deer poachers in the western United States: A research note. Deviant Behav. 1999, 20, 233-252.

16. Maruna, S.; Copes, H. What have we learned from five decades of neutralization research? Crime Justice 2005, 32, 221-320. [CrossRef]

17. Hunter, L.M.; Hatch, A.; Johnson, A. Cross-national gender variation in environmental behaviors. Soc. Sci. Q. 2004, 85, 677-694. [CrossRef]

18. Sotamenou, J.; De Jaeger, S.; Rousseau, S. Drivers of legal and illegal solid waste disposal in the Global South-The case of households in Yaoundé (Cameroon). J. Environ. Manag. 2019, 240, 321-330. [CrossRef] [PubMed]

19. Chu, A.M.; Chau, P.Y.; So, M.K. Explaining the misuse of information systems resources in the workplace: A dual-process approach. J. Bus. Ethics 2015, 131, 209-225. [CrossRef]

20. Pogarsky, G. Projected offending and implications for heterotypic continuity. Criminology 2004, 42, 111-135. [CrossRef]

21. Kaiser, H.F. An index of factorial simplicity. Psychometrika 1974, 39, 31-36. [CrossRef]

22. Costello, A.B.; Osborne, J.W. Best practices in exploratory factor analysis: Four recommendations for getting the most from your analysis. Pract. Assess. Res. Eval. 2005, 10, 7.

23. Kaiser, H.F. The application of electronic computers to factor analysis. Educ. Psychol. Meas. 1960, 20, 141-151. [CrossRef]

24. Cattell, R.B. The scree test for the number of factors. Multivar. Behav. Res. 1966, 1, 245-276. 
25. Bennett, R.; Robinson, S.L. Development of a measure of workplace deviance. J. Appl. Psychol. 2000, 85, 349-360. [CrossRef]

26. Vlek, C.; Steg, L. Human behavior and environmental sustainability: Problems, driving forces, and research topics. J. Soc. Issues 2007, 63, 1-19. [CrossRef]

27. Fischer, J.; Dyball, R.; Fazey, I.; Gross, C.; Dovers, S.; Ehrlich, P.R.; Brulle, R.J.; Christensen, C.; Borden, R.J. Human behavior and sustainability. Front. Ecol. Environ. 2012, 10, 153-160. [CrossRef]

28. Chu, A.M.Y.; So, M.K.P.; Chung, R.S.W. Applying the randomized response technique in business ethics research: The misuse of information systems resources in the workplace. J. Bus. Ethics 2018, 151, 195-212. [CrossRef]

29. Li, Z.; Man, S.S.; Chan, A.H.S.; Zhu, J. Integration of theory of planned behavior, sensation seeking, and risk perception to explain the risky driving behavior of truck drivers. Sustainability 2021, 13, 5214. [CrossRef]

30. Awang, Y.; Ismail, S. Determinants of financial reporting fraud intention among accounting practitioners in the banking sector: Malaysian evidence. Int. J. Ethics Syst. 2018, 34, 32-54. [CrossRef]

31. Chong, A.C.Y.; Chu, A.M.Y.; So, M.K.P.; Chung, R.S.W. Asking sensitive questions using the randomized response approach in public health research: An empirical study on the factors of illegal waste disposal. Int. J. Environ. Res. Public Health 2019, 16, 970. [CrossRef]

32. Jackson, L.; Pang, M.F.; Brown, E.; Cain, S.; Dingle, C.; Bonebrake, T. Environmental attitudes and behaviors among secondary students in Hong Kong. Int. J. Comp. Educ. Dev. 2016, 18, 70-80. [CrossRef]

33. Hong Kong Education Bureau. Environment Report. Available online: https://www.edb.gov.hk/attachment/en/about-edb/ publications-stat/environmental-report/Environmental\%20Report\%202016_\%20eng_fair.pdf (accessed on 15 May 2021).

34. Miner, K.J.; Rampedi, I.T.; Ifegbesan, A.P.; Machete, F. Survey on household awareness and willingness to participate in e-waste management in Jos, Plateau State, Nigeria. Sustainability 2020, 12, 1047. [CrossRef]

35. Benson, M.L.; Madensen, T. Situational Crime Prevention and White-Collar Crime. In International Handbook of Corporate and White Collar Crime; Pontell, H., Geis, G., Eds.; Springer: New York, NY, USA, 2007; pp. 609-626.

36. Huisman, W.; Van Erp, J. Opportunities for environmental crime: A test of situational crime prevention theory. Br. J. Criminol. 2013, 53, 1178-1200. [CrossRef]

37. Wortley, R.; Mazerolle, L. Environmental Criminology and Crime Analysis; Willan Publishing: Cullompton, UK, 2008.

38. McEachan, R.R.C.; Conner, M.; Taylor, N.J.; Lawton, R.J. Prospective prediction of health-related behaviours with the theory of planned behaviour: A meta-analysis. Health Psychol. Rev. 2011, 5, 97-144. [CrossRef]

39. Sheeran, P.; Klein, W.M.P.; Rothman, A.J. Health behaviour change: Moving from observation to intervention. Annu. Rev. Psychol. 2017, 68, 573-600. [CrossRef] [PubMed]

40. Viljoen, J.M.M.; Schenck, C.J.; Volschenk, L.; Blaauw, P.F.; Grobler, L. Household waste management practices and challenges in a rural remote town in the Hantam Municipality in the Northern Cape, South Africa. Sustainability 2021, 13, 5903. [CrossRef] 